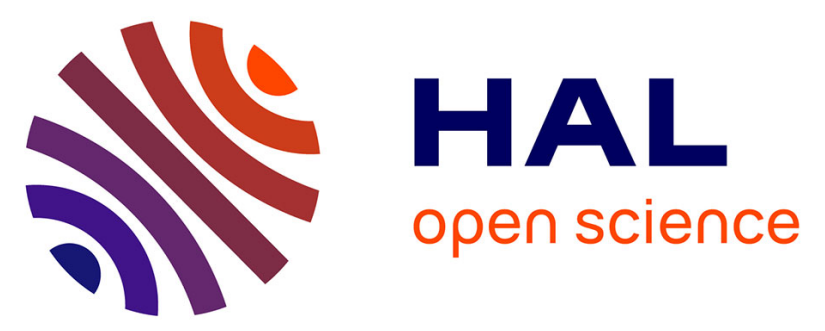

\title{
Towards Naked Zinc(II) in the Condensed Phase: A Highly Lewis Acidic Zn II Dication Stabilized by Weakly Coordinating Carborate Anions
}

\author{
Nicolas Adet, David Specklin, Christophe Gourlaouen, Thibault Damiens, \\ Béatrice Jacques, Rudolf Wehmschulte, Samuel Dagorne
}

\section{To cite this version:}

Nicolas Adet, David Specklin, Christophe Gourlaouen, Thibault Damiens, Béatrice Jacques, et al.. Towards Naked Zinc(II) in the Condensed Phase: A Highly Lewis Acidic Zn II Dication Stabilized by Weakly Coordinating Carborate Anions. Angewandte Chemie International Edition, In press, 10.1002/anie.202012287 . hal-03098198

\section{HAL Id: hal-03098198 \\ https://hal.science/hal-03098198}

Submitted on 5 Jan 2021

HAL is a multi-disciplinary open access archive for the deposit and dissemination of scientific research documents, whether they are published or not. The documents may come from teaching and research institutions in France or abroad, or from public or private research centers.
L'archive ouverte pluridisciplinaire HAL, est destinée au dépôt et à la diffusion de documents scientifiques de niveau recherche, publiés ou non, émanant des établissements d'enseignement et de recherche français ou étrangers, des laboratoires publics ou privés. 


\section{Table of Contents Only}

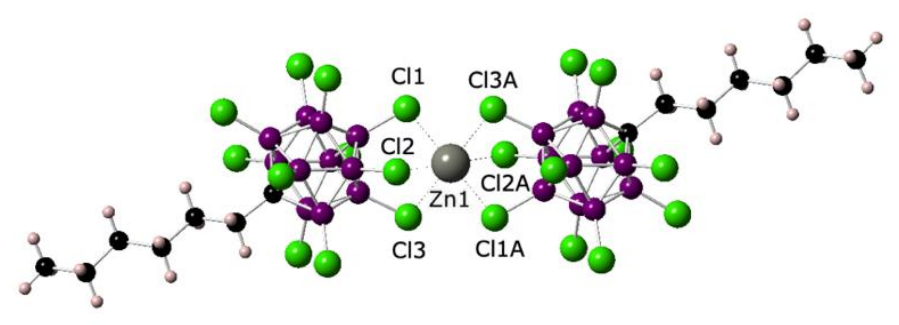

A salt compound containing a formal $\mathrm{Zn}^{2+}$ dication only stabilized by weakly coordinated carborate anions was first structurally characterized and shown to be soluble in low polarity solvents. Based on its reactivity with alkene, alkyne and in hydrosilylation catalysis, it is a strong Lewis acid, possibly the strongest Zn-based Lewis acid to date.

Keywords: Zinc - Lewis acid - cation - hydrosilylation - carborate 


\section{Towards "naked" $\mathrm{Zn}^{2+}$ in the condensed phase: synthesis, structure and reactivity of a} highly Lewis acidic Zn(II) dication stabilized by weakly coordinating carborate anions

Nicolas Adet, ${ }^{\mathrm{a}}$ David Specklin, ${ }^{\mathrm{a}}$ Christophe Gourlaouen, ${ }^{\mathrm{a}}$ Thibault Damiens, ${ }^{\mathrm{a}}$ Béatrice Jacques, ${ }^{a}$ Rudolf J. Wehmschulte ${ }^{\mathrm{b}, *}$ and Samuel Dagorne ${ }^{\mathrm{a},{ }^{*}}$

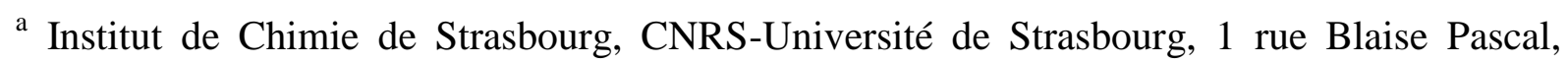
67000 Strasbourg, France.

b Chemistry Program, Florida Institute of Technology, 150 West University Boulevard, Melbourne, Florida 32901-6975, United States

Abstract. The employment of the hexyl-substituted anion [HexCB$\left.{ }_{11} \mathrm{Cl}_{11}\right]^{-}$allowed for the first time the synthesis of a $\mathrm{Zn}(\mathrm{II})$ species, $\mathrm{Zn}\left[\mathrm{HexCB} \mathrm{CB}_{11} \mathrm{Cl}_{11}\right]_{2}, \mathbf{3}$, in which the $\mathrm{Zn}^{2+}$ cation is only weakly coordinated to two carborate counterions and that is soluble in low polarity organic solvents such as bromobenzene. DOSY NMR studies show the facile displacement of at least one of the counterions, and this near "nakedness" of the cation results in high catalytic activity in the hydrosilylation of 1-hexene and 1-methyl-1cyclohexene. Fluoride Ion Affinity (FIA) calculations reveal a solution Lewis acidity of $3\left(\mathrm{FIA}=262.1 \mathrm{~kJ} \cdot \mathrm{mol}^{-1}\right)$ that is higher than that of the landmark Lewis acid $\mathrm{B}\left(\mathrm{C}_{6} \mathrm{~F}_{5}\right)_{3}\left(\mathrm{FIA}=220.5 \mathrm{~kJ} \cdot \mathrm{mol}^{-1}\right)$. This high Lewis acidity leads to a high activity in catalytic $\mathrm{CO}_{2}$ and $\mathrm{Ph}_{2} \mathrm{CO}$ reduction by $\mathrm{Et}_{3} \mathrm{SiH}$ and hydrogenation of 1,1-diphenylethylene using 1,4-cyclohexadiene as the hydrogen source. Compound $\mathbf{3}$ was characterized by multinuclear NMR spectroscopy, mass spectrometry, single crystal X-ray diffraction and DFT studies.

\footnotetext{
*Email: rwehmsch@fit.edu, dagorne@unistra.fr
} 
Metal-centered Lewis acids are widespread powerful and versatile reagents in all areas of chemistry, ranging from synthetic chemistry to material science, due to the utility of various Lewis acidic metal ions for substrate activation/functionalization. ${ }^{1}$ In that regard, lowcoordinate ligand-supported metal cations have attracted attention over the years to access electrophilic/reactive species for enhanced reactivity. ${ }^{2}$ Ideally though, the simplest of all metal Lewis acids, i.e. ligand-free ("naked") or weakly coordinated metal cations, should be most reactive for chemical functionalization since direct "naked" metal cation/substrate activation should maximize electrophilic activation. However, access to stable ligand-free metal ions in the condensed phase has thus far remained a major challenge, which is due to their high electrophilicity, their instability and/or insolubility in common organic media. Over the past years, the use of modern weakly coordinating anions (WCAs) such as $\left[\mathrm{B}\left(\mathrm{C}_{6} \mathrm{~F}_{5}\right)_{4}\right]^{-}$, $\left[\mathrm{Al}\left(\mathrm{OR}^{\mathrm{F}}\right)_{4}\right]^{-}$and halogenated carborate ions (most notably $\left[\mathrm{CH}_{6} \mathrm{~B}_{6} \mathrm{X}_{6}\right]^{-}$and $\left[\mathrm{CHB}_{11} \mathrm{X}_{11}\right]^{-} ; \mathrm{X}=$ $\mathrm{Cl}$, I) for minimal cation-anion interactions, ${ }^{3}$ has led to the characterization of several monovalent and $\mathrm{M}^{+}$Lewis acids only stabilized by a low basicity solvent and a WCA, including $\mathrm{Li}^{+}, \mathrm{Ag}^{+}$and $\mathrm{M}^{+}\left(\mathrm{M}=\right.$ group 13 metal) salts. ${ }^{4,5,6,7,8,9,10}$ Such salts display enhanced reactivity due to weaker cation-anion interactions, including the acceleration of Diels-Alder reactions with $\mathrm{Li}\left[\mathrm{B}\left\{\mathrm{C}_{6} \mathrm{H}_{3}\left(\mathrm{CF}_{3}\right)_{2}-3,5\right\}_{4}\right],{ }^{4}$ carbonyl-ene reactions catalyzed by $\mathrm{Li}\left[\mathrm{B}\left(\mathrm{C}_{6} \mathrm{~F}_{5}\right)_{4}\right],{ }^{5}$ and the polymerization of isobutene catalyzed by $\left[\mathrm{Ga}(\text { arene })_{3}\right]\left[\mathrm{Al}\left\{\mathrm{OC}\left(\mathrm{CF}_{3}\right)_{3}\right\}_{4}\right] .{ }^{6}$ Also noteworthy, an $\mathrm{Ag}(\mathrm{I})$ complex with two $\mathrm{P}_{4}$ molecules coordinated to one $\mathrm{Ag}^{+}$cation was characterized. ${ }^{11}$ To date, weakly coordinated or "naked" $\mathrm{M}^{2+}$ divalent cations that are stable at room temperature and soluble in low basicity/polarity solvents are unknown, despite their interest as strong Lewis acids/electrophiles. Compounds such as $\mathrm{M}\left[\mathrm{BF}_{4}\right]_{2}$ or $\mathrm{M}\left[\mathrm{EF}_{6}\right]_{2}(\mathrm{M}=+2$ cation, $\mathrm{E}=\mathrm{As}, \mathrm{Sb}$ ), prepared by the reaction of $\mathrm{MF}_{2}$ with $\mathrm{BF}_{3}$ or $\mathrm{EF}_{5}$ in anhydrous $\mathrm{HF}$, are known but insoluble in most organic solvents. ${ }^{12}$ Species $\mathrm{Hg}\left[\mathrm{B}_{12} \mathrm{H}_{12}\right]^{13}$ and $\mathrm{Ni}\left[\mathrm{B}_{12} \mathrm{H}_{12}\right],{ }^{14}$ were obtained from dehydration of hydrate salts $\mathrm{Hg}\left(\mathrm{H}_{2} \mathrm{O}\right)_{x}\left[\mathrm{~B}_{12} \mathrm{H}_{12}\right]$ and $\mathrm{Ni}\left(\mathrm{H}_{2} \mathrm{O}\right)_{6}\left[\mathrm{~B}_{12} \mathrm{H}_{12}\right]$, 
respectively. The solvent-free zinc salt $\mathrm{Zn}\left[\mathrm{Al}\left\{\mathrm{OCH}\left(\mathrm{CF}_{3}\right)_{2}\right\}_{4}\right]_{2}$ was also recently characterized, but the rather short $\mathrm{Zn} \cdots \mathrm{O}$ contacts (1.986 $\AA$ avg.) significantly quench the Lewis acidity of the $\mathrm{Zn}^{2+}$ center as deduced from solid state and solution data. ${ }^{15} \mathrm{Zn}(\mathrm{II})$ complexes of electronrich arenes $\mathrm{Zn}\left(\mathrm{SbF}_{6}\right)_{2} \cdot \mathrm{C}_{6} \mathrm{Me}_{6}$ and $\mathrm{Zn}\left(\mathrm{SbF}_{6}\right)_{2} \cdot \mathrm{C}_{6} \mathrm{HMe}_{5}$ have only been characterized by NMR spectroscopy in $\mathrm{SO}_{2}$ solution. ${ }^{16}$ Only very recently, the structure of $\operatorname{Sr}\left[\mathrm{Al}\left\{\mathrm{OC}\left(\mathrm{CF}_{3}\right)_{3}\right\}_{4}\right]_{2}$ was reported, which features a partially "naked" large and therefore less Lewis acidic $\mathrm{Sr}^{2+}$ cation. $^{17}$

$\mathrm{Zn}(\mathrm{II})$ salts, considered as borderline Lewis acids in Pearson's HSAB classification, are commonly used as Lewis acids for the mediation of various stoichiometric and catalytic transformations. Well-defined $\mathrm{Zn}$ organometallics such as arylzinc species $\mathrm{Zn}\left(\mathrm{C}_{6} \mathrm{~F}_{5}\right)_{2}$ are well-established Lewis acid catalysts, especially for the polymerization of various monomers. ${ }^{18}$ Of particular interest, ligand-supported $\mathrm{Zn}(\mathrm{II})$-based organocations are wellestablished electrophilic species but have attracted recent attention since $\mathrm{Zn}$ is an Earthabundant and inexpensive metal source. ${ }^{2 \mathrm{a}, 19}$ Recent developments, including from our labs, have shown that a number of reactive low-coordinate (two- and three-coordinate) $\mathrm{Zn}$ (II) cations, all consisting of ligand-stabilized $[\mathrm{Zn}-\mathrm{R}]^{+}$mono-cations $(\mathrm{R}=$ alkyl, aryl $)$, may behave as Lewis acids for the mediation of various catalytic reactions ranging from alkyne hydroamination to alkyne, alkene and $\mathrm{CO}_{2}$ hydrosilylation. ${ }^{20}$ We herein report on the synthesis and structural characterization of the first weakly coordinated $\mathrm{Zn}^{2+}$ cation (isolated as $\mathrm{Zn}[\mathrm{WCA}]_{2}$ ) that is stable and soluble in low polarity organic solvents. We also provide preliminary reactivity studies indicating an unprecedentedly strong Lewis acidity for a $\mathrm{Zn}$ (II) species.

As an entry to $\mathrm{Zn}[\mathrm{WCA}]_{2}$, the fully chlorinated carborate anion $\left[\mathrm{CHB}_{11} \mathrm{Cl}_{11}\right]^{-}$, which is one of the least coordinating and least reactive anions known thus far, ${ }^{21}$ was initially tested to access 
stable and characterizable $\mathrm{Zn}[\mathrm{WCA}]_{2}$ salts. To generate a formal $\mathrm{Zn}^{2+}$ di-cation in a low (Lewis) basicity medium, $\mathrm{Et}^{-}$abstraction from $\left[\mathrm{EtZn}\left(\mathrm{C}_{6} \mathrm{H}_{6}\right)\right]\left[\mathrm{CHB}_{11} \mathrm{Cl}_{11}\right](\mathbf{1}),{ }^{20 \mathrm{a}}$ a formal source of the $[\mathrm{Zn}-\mathrm{Et}]^{+}$mono-cation, with $\left[\mathrm{Ph}_{3} \mathrm{C}\right]\left[\mathrm{CHB}_{11} \mathrm{Cl}_{11}\right]$ was first attempted. The reaction of a 1/1 1/[ $\left.\mathrm{Ph}_{3} \mathrm{C}\right]\left[\mathrm{CHB}_{11} \mathrm{Cl}_{11}\right]$ mixture $\left(\mathrm{C}_{6} \mathrm{D}_{5} \mathrm{Br}, 24 \mathrm{~h}\right.$ at $\mathrm{RT}$ and then $24 \mathrm{~h}$ at $\left.95{ }^{\circ} \mathrm{C}\right)$ led to complete consumption of both reactants, the formation of $\mathrm{Ph}_{3} \mathrm{CH}$ and ethylene (as deduced from NMR data) in line with $\mathrm{Et}^{-}$abstraction from the $[\mathrm{Zn}-\mathrm{Et}]^{+}$fragment, along with the precipitation of colorless solid, possibly $\mathrm{Zn}\left[\mathrm{CHB}_{11} \mathrm{Cl}_{11}\right]_{2}$. However, poor solubility precluded structural identification whether in solution or in the solid state, prompting us towards the synthesis of a more soluble WCA as a $\mathrm{Zn}^{2+}$ counterion. ${ }^{22}$ To this end, anion $\left[\mathrm{CHB}_{11} \mathrm{Cl}_{11}\right]^{-}$was $\mathrm{C}$-functionalized by a hexyl group to access the more soluble carborate anion $\left[\mathrm{HexCB}_{11} \mathrm{Cl}_{11}\right]^{-23}$ The $\mathrm{C}-\mathrm{H}$ deprotonation of $\mathrm{Cs}\left[\mathrm{CHB}_{11} \mathrm{Cl}_{11}\right]$ and subsequent hexyl functionalization afforded $\mathrm{Cs}\left[\mathrm{HexCB}{ }_{11} \mathrm{Cl}_{11}\right]$, isolated in $74 \%$ yield (Scheme 1). Salt metathesis between $\mathrm{Cs}\left[\mathrm{HexCB}{ }_{11} \mathrm{Cl}_{11}\right]$ and $\mathrm{Ph}_{3} \mathrm{CCl}$ led to the corresponding trityl salt $\left[\mathrm{Ph}_{3} \mathrm{C}\right]\left[\mathrm{HexCB}_{11} \mathrm{Cl}_{11}\right](\mathbf{2}, 73 \%$ yield), as confirmed by X-ray crystallographic analysis (see SI). IR data for salt $\left[\mathrm{HNOct}_{3}\right]\left[\mathrm{HexCB}_{11} \mathrm{Cl}_{11}\right]$ (see SI for its preparation) agree with a slightly more Lewis basic $\left[\mathrm{HexCB}{ }_{11} \mathrm{Cl}_{11}\right]^{-}$anion compared to $\left[\mathrm{CHB}_{11} \mathrm{Cl}_{11}\right]^{-}\left(v_{\mathrm{NH}}=3176\right.$ and $3180 \mathrm{~cm}^{-}$ ${ }^{1}$, respectively) due to the better electron donor ability of the hexyl group ( $v s$. hydrogen). ${ }^{21}$ 


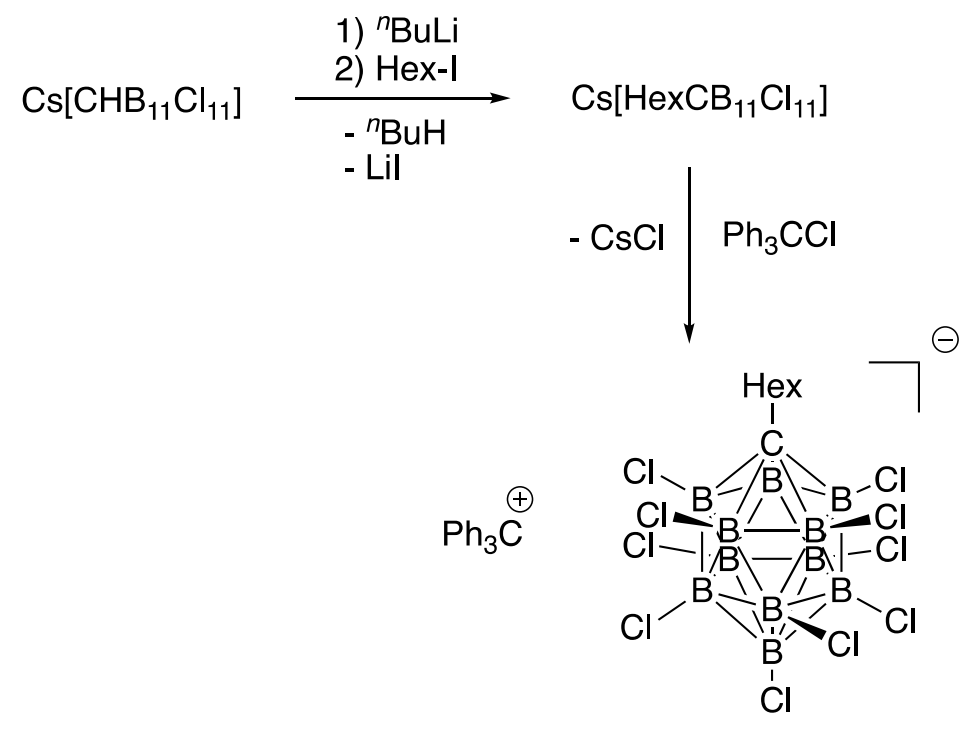

$\left[\mathrm{Ph}_{3} \mathrm{C}\right]\left[\mathrm{HexCB}_{11} \mathrm{Cl}_{11}\right](2)$

Scheme 1. Synthesis of trityl salt $\left[\mathrm{Ph}_{3} \mathrm{C}\right]\left[\mathrm{HexCB}_{11} \mathrm{Cl}_{11}\right](2)$

The synthesis of $\mathrm{Zn}\left[\mathrm{HexCB}{ }_{11} \mathrm{Cl}_{11}\right]_{2}\left(\mathbf{3}\right.$, Scheme 2) was achieved directly from $\mathrm{ZnEt}_{2}$ and trityl salt 2. Thus, the double ionization reaction of $\mathrm{ZnEt}_{2}$ with 2 equiv of $2\left(\mathrm{PhBr}, 60{ }^{\circ} \mathrm{C}\right.$, $6 \mathrm{~h}$ ) led to the quantitative formation of 3 along with $\mathrm{Ph}_{3} \mathrm{CH}$ and ethylene, as deduced from NMR data. Species 3, isolated in $71 \%$ yield, is soluble and stable for days in $\mathrm{PhBr}(\mathrm{RT})$ but decomposes within minutes in $\mathrm{CH}_{2} \mathrm{Cl}_{2}$ (RT) to unknown species.

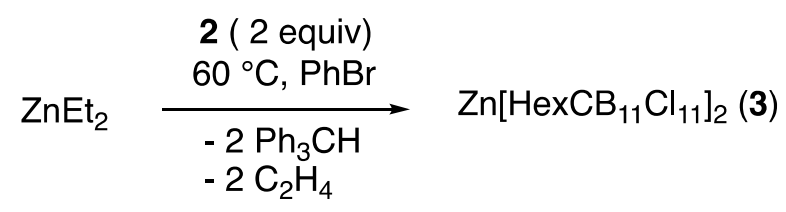

Scheme 2. Synthesis of $\mathrm{Zn}\left[\mathrm{HexCB}{ }_{11} \mathrm{Cl}_{11}\right]_{2}(3)$

The solid state molecular structure of $\mathbf{3}$ was determined through XRD studies (Figure 1). It crystallizes as an ion pair with a central $\mathrm{Zn}^{2+}$ cation in a slightly distorted octahedral environment since surrounded by two $\left[\mathrm{HexCB}_{11} \mathrm{Cl}_{11}\right]^{-}$anions coordinated in a $\kappa^{3}-\mathrm{Cl}_{3}$ fashion. The $\mathrm{Zn} \cdots \mathrm{Cl}$ contacts $(2.495 \AA$ average $)$ are shorter than those in compound 
$\left[\mathrm{EtZn}\left(\mathrm{C}_{6} \mathrm{H}_{6}\right)\right]\left[\mathrm{CHB}_{11} \mathrm{Cl}_{11}\right](2.613 \AA$ average $)$, reflecting the higher charge at $\mathrm{Zn}$ in $\mathbf{3}$ and thus stronger electrostatic interactions. As has been observed previously, ${ }^{20 \mathrm{a}, 31 \mathrm{~b}}$ the coordination to the $\mathrm{Zn}^{2+}$ cation results in a slight elongation of the involved $\mathrm{B}-\mathrm{Cl}$ bonds $(1.801 \AA$ average versus $1.763 \AA$ average).

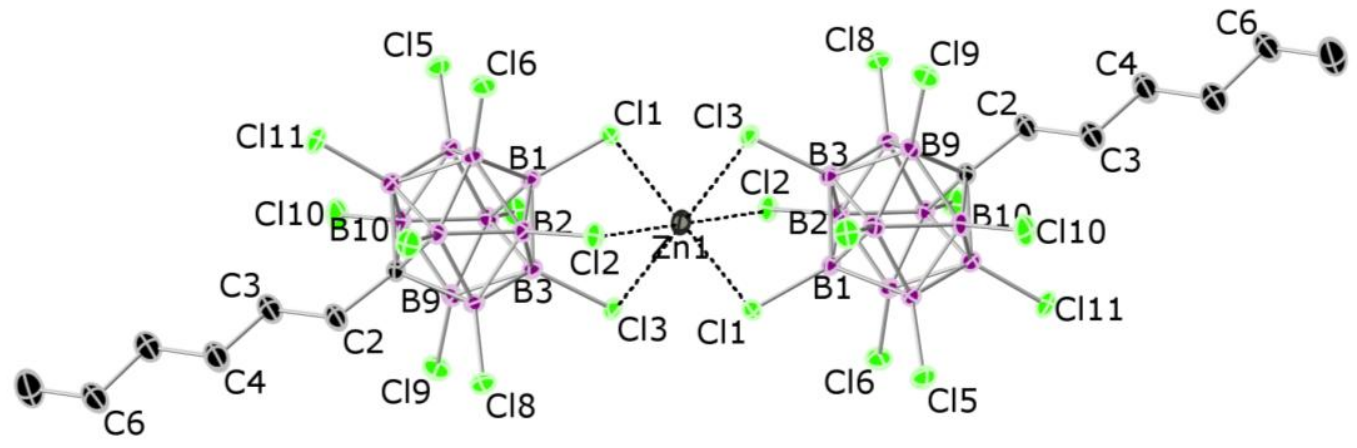

Figure 1. Molecular structure (ORTEP view, $50 \%$ probability) of $\mathrm{Zn}\left[\mathrm{HexCB}{ }_{11} \mathrm{Cl}_{11}\right]_{2}(3)$. $\mathrm{H}$ atoms have been omitted for clarity. Selected distances $(\AA)$ and angles $\left(^{\circ}\right): \operatorname{Zn}(1) \cdots \mathrm{Cl}(1)$ 2.4544(7), $\mathrm{Zn}(1) \cdots \mathrm{Cl}(2) 2.4905(7), \mathrm{Zn}(1) \cdots \mathrm{Cl}(3) 2.5456(7), \mathrm{B}-\mathrm{Cl}(\cdots \mathrm{Zn}) \quad 1.810$ (avg.), B-Cl 1.763(avg.), Cl(1)-Zn-Cl(1A) 180, Cl(1)-Zn-Cl(2) 90.85(2), Cl(1)-Zn-Cl(3) 86.94(2).

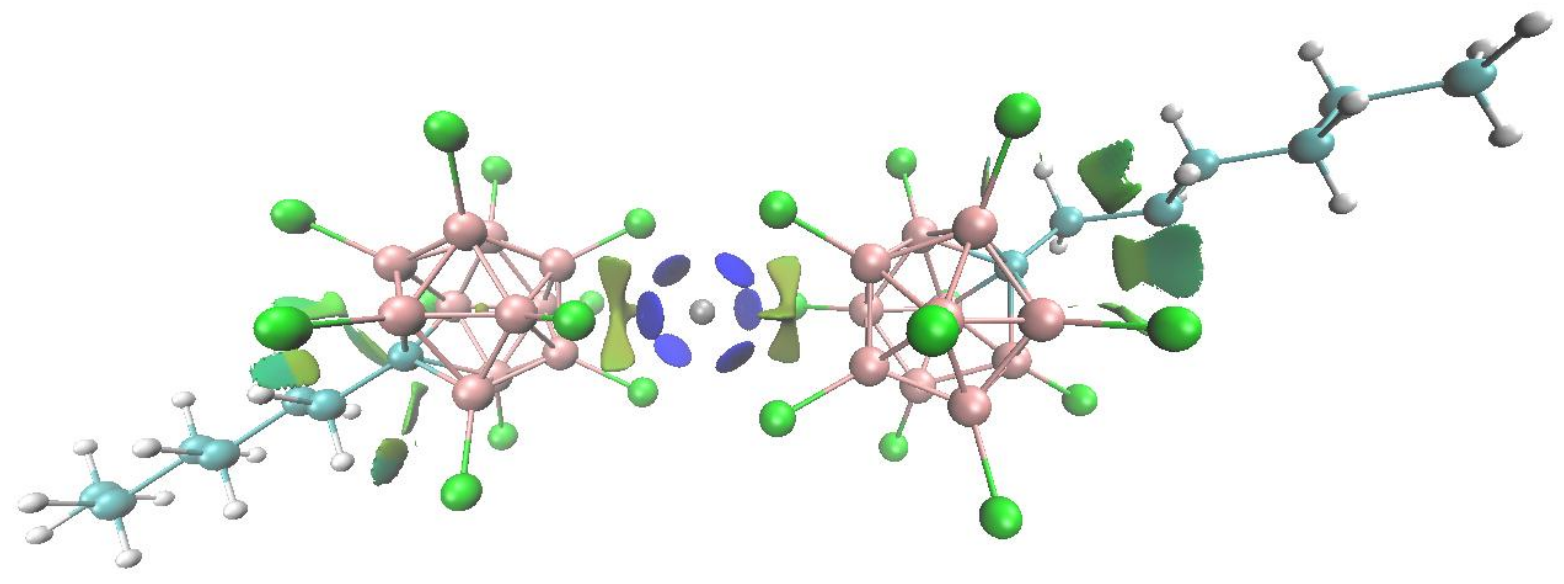

Figure 2. DFT-estimated (B3LYP/6-31+G**) Non-Covalent Interaction (NCI) analysis of a model species for 3. Attractive electrostatic interactions appear in blue areas and attractive dispersion forces appear in green areas. 
Computations on the electronic structure of species 3 using Electron Localization Function (ELF, see SI) and Non-Covalent Interactions (NCI, Figure 2) analysis agree with purely electrostatic interactions (and no covalence) between the central $\mathrm{Zn}^{2+}$ cation and the surrounding chlorines. Importantly, species $\mathbf{3}$ is clearly dynamic in solution as deduced by NMR data indicating a ready cation/anion dissociation at room temperature in $\mathrm{C}_{6} \mathrm{D}_{5} \mathrm{Br}$. Thus, DOSY NMR measurements for $\mathbf{3}$ led to an estimated hydrodynamic volume of $1100 \AA$, i.e. lying between those of free $\left[\mathrm{HexCB}_{11} \mathrm{Cl}_{11}\right]^{-}$anion (around $850 \AA$ ) and solid-state characterized $\mathbf{3}$ (around $1650 \AA$ ). This is consistent with fast cation/anion dissociation in $\mathbf{3}$ on the NMR timescale with stabilization of the $\mathrm{Zn}^{2+}$ by $\mathrm{PhBr}$ coordination. ${ }^{24}$ This is corroborated by DFT calculations (B3LYP/6-31+G**, $\mathrm{PhBr}$ as solvent, modelled in the presence of one $\mathrm{PhBr}$ molecule) with the dissociation of 3 to $\left[\mathrm{Zn}\left(\mathrm{HexCB}{ }_{11} \mathrm{Cl}_{11}\right)(\mathrm{PhBr})\right]^{+}$and free $\left[\mathrm{HexCB}_{11} \mathrm{Cl}_{11}\right]^{-}$anion computed to occur at little energy cost $\left(\Delta \mathrm{G}=28.4 \mathrm{~kJ} \cdot \mathrm{mol}^{-1}\right) .^{25}$ Furthermore, to assess the Lewis acidity of species 3, its Fluoride Ion Affinity (FIA) was DFT-estimated (B3LYP/6-31+G**, PhBr, see SI). ${ }^{26,27}$ In agreement with a highly electrophilic $\mathrm{Zn}(\mathrm{II})$ center, FIA calculations are consistent with $3\left(\right.$ FIA $=262.1 \mathrm{~kJ} \cdot \mathrm{mol}^{-1}$ ) being significantly more Lewis acidic than the ion-pair $\left[\mathrm{EtZn}\left(\mathrm{C}_{6} \mathrm{H}_{6}\right)\right]\left[\mathrm{CHB}_{11} \mathrm{Cl}_{11}\right](\mathrm{FIA}=$ $\left.224.3 \mathrm{~kJ} \cdot \mathrm{mol}^{-1}\right)$, the two-coordinate $(\mathrm{NHC}) \mathrm{Zn}-\mathrm{C}_{6} \mathrm{~F}_{5}{ }^{+}$cation $(\mathrm{NHC}=\mathrm{IDipp}$, FIA $=185.5$ $\left.\mathrm{kJ} \cdot \mathrm{mol}^{-1}\right)$ and the landmark Lewis acid $\mathrm{B}\left(\mathrm{C}_{6} \mathrm{~F}_{5}\right)_{3}\left(\mathrm{FIA}=220.5 \mathrm{~kJ} \cdot \mathrm{mol}^{-1}\right)$.

To substantiate the electrophilicity of the $\mathrm{Zn}(\mathrm{II})$ center in $\mathbf{3}$, it was first reacted with unsaturated substrates such as 1-hexene and 1-octyne, as well as $\mathrm{H}_{2} .{ }^{1} \mathrm{H}$ NMR data of a 1/1 3/1-hexene mixture $\left(\mathrm{RT}, \mathrm{C}_{6} \mathrm{D}_{5} \mathrm{Br}\right)$ agree with immediate reaction, but a ready polymerization of 1-hexene precluded any adduct characterization. This was further confirmed by the reaction of a $1 / 100$ 3/1-hexene mixture ( $R T, C_{6} D_{5} \mathrm{Br}$ ) leading to a $61 \%$ conversion of 1 hexene to poorly defined poly(1-hexene) oligomers within $3 \mathrm{~h}$, as deduced from GPC data $\left(M_{\mathrm{n}}=924 \mathrm{~g} . \mathrm{mol}^{-1}, Ð=1.76\right)$. DFT $\left(\mathrm{B} 3 \mathrm{LYP} / 6-31+\mathrm{G}^{* *}, \mathrm{PhBr}\right)$ calculations predict that the 
formation of $\pi$-adduct $\left[\left(\mathrm{HexCB}_{11} \mathrm{Cl}_{11}\right) \mathrm{Zn} \text { (propene) }\right]^{+}$(along with free carborate) from $\mathbf{3}$ and propene should occur under the reaction conditions $\left(\Delta \mathrm{G}=5.9 \mathrm{~kJ} \cdot \mathrm{mol}^{-1}\right)$, reflecting the strong Lewis acidity of $\mathrm{Zn}(\mathrm{II})$ center. ${ }^{28}$ Alkene oligo-/poly-merization mediated by Lewis acidic metal complexes is well-established. ${ }^{2 a}$ Likewise, 1 -octyne immediately reacts with 1 equiv of 3 (RT, $\mathrm{C}_{6} \mathrm{D}_{5} \mathrm{Br}$ ) according to ${ }^{1} \mathrm{H}$ NMR data, provoking a significant downfield of the alkynyl proton ${ }^{1} \mathrm{H}$ NMR shift (s, br, $\left.\delta=4.40 \mathrm{ppm}\right) v s$. that of free 1-octyne (t, $\delta=1.92 \mathrm{ppm}$ ), in line with an enhanced vinylic character. Though the latter suggests the formation of a $\mathrm{Zn}$-alkyne adduct, further characterization was precluded due its decomposition within a couple of hours to unknown species. According to DFT (B3LYP/6-31+G**, PhBr) calculations with propyne as the modelled alkyne, the formation of $\pi$-adduct $\left[\left(\mathrm{HexCB}_{11} \mathrm{Cl}_{11}\right) \mathrm{Zn} \text { (propyne) }\right]^{+}$(along with free carborate) from 3 and propyne also occurs at little energy cost $\left(\Delta \mathrm{G}=7.9 \mathrm{~kJ} \cdot \mathrm{mol}^{-1}\right)$, in agreement with a labile Zn-alkyne adduct at RT. The reactivity of salt $\mathbf{3}$ with $\mathrm{H}_{2}$ was also probed: no apparent reaction was observed between 3 under $\mathrm{H}_{2}\left(3\right.$ bar) at $\mathrm{RT}$ or $90{ }^{\circ} \mathrm{C}$ in $\mathrm{C}_{6} \mathrm{D}_{5} \mathrm{Br}$ for $2 \mathrm{~h}$.

Next, species 3 was evaluated in hydrosilylation catalysis (alkene and $\mathrm{CO}_{2}$ ) to probe the ability of $\mathbf{3}$ for Si-H activation. ${ }^{29}$ In the presence of $\mathrm{HSiEt}_{3}$, species 3 (1 mol\%) catalyzes fast 1-hexene hydrosilylation at room temperature $\left(\mathrm{C}_{6} \mathrm{D}_{5} \mathrm{Br}\right)$ with a quantitative conversion to 4 within $15 \mathrm{~min}$ (Scheme 3). As a comparison, $\left[\mathrm{EtZn}\left(\mathrm{C}_{6} \mathrm{H}_{6}\right)\right]\left[\mathrm{CHB}_{11} \mathrm{Cl}_{11}\right]$ is an inactive catalyst at room temperature while cation $\left[(\mathrm{IDipp}) \mathrm{Zn}-\mathrm{C}_{6} \mathrm{~F}_{5}\right]^{+}$and $\mathrm{B}\left(\mathrm{C}_{6} \mathrm{~F}_{5}\right)_{3}$ proceed much more slowly. ${ }^{20 a, 20 c, 30}$ A similar high activity was observed for the hydrosilylation of 1methylcyclohexene catalyzed by $3\left(1 \mathrm{~mol} \%, \mathrm{C}_{6} \mathrm{D}_{5} \mathrm{Br}, \mathrm{RT}, 15 \mathrm{~min}\right)$ and selectively led to the cis-hydrosilylated product $\mathbf{5}$, consistent with a selective anti-1,2-addition of $\mathrm{Si}-\mathrm{H}$ to the $\mathrm{C}=\mathrm{C}$ bond. Though species 3 remains intact after olefin hydrosilylation catalysis, an NMR control experiment of a $\mathrm{HSiEt}_{3} / \mathbf{3}$ mixture showed that species 3 interacts with $\mathrm{HSiEt}_{3}$ (2 equiv, $\mathrm{PhBr}$, 
RT) with an immediate broadening of the $\mathrm{Si}-H{ }^{1} \mathrm{H}$ NMR resonance, in line with $\mathrm{Si}-\mathrm{H}$ activation by the $\mathrm{Zn}(\mathrm{II})$ cationic center (see $\mathrm{SI}$ ).

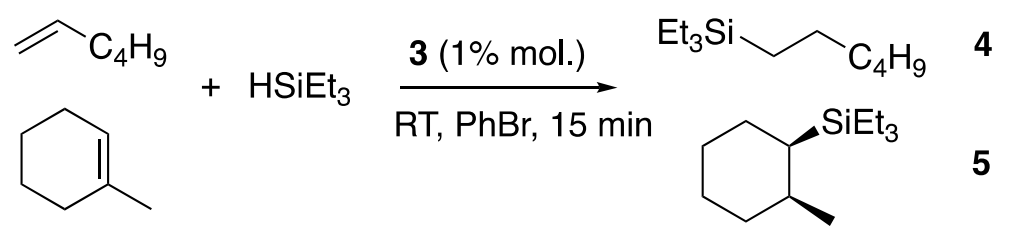

Scheme 3. Olefin hydrosilylation catalyzed by $\mathrm{Zn}(\mathrm{II})$ species 3.

Consistent with $3 / \mathrm{HSiEt}_{3}$ interactions, $\mathrm{HSiEt}_{3}$ redistribution was observed over time in the presence of a catalytic amount of $\mathbf{3}\left(1 \mathrm{~mol} \%\right.$ vs. $\left.\mathrm{HSiEt}_{3}\right)$, with the formation of a mixture of $\mathrm{SiEt}_{4}\left(38 \%\right.$ conv. of initial $\left.\mathrm{HSiEt}_{3}\right), \mathrm{HSiEt}_{3}, \mathrm{H}_{2} \mathrm{SiEt}_{2}$ and $\mathrm{H}_{3} \mathrm{SiEt}$ after $16 \mathrm{~h}$ at room temperature, as indicated by ${ }^{1} \mathrm{H},{ }^{13} \mathrm{C},{ }^{29} \mathrm{Si}$ and $2 \mathrm{D} \mathrm{NMR}$ analysis (see SI). Interestingly, according to DFT computation (B3LYP/6-31+G**, $\mathrm{PhBr}$ ), the formation of the

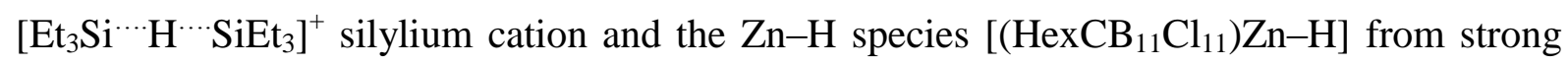
Lewis acid 3 and 2 equiv of $\mathrm{HSiEt}_{3}$ is possible at low energy cost $\left(\Delta \mathrm{G}=25.9 \mathrm{~kJ} \cdot \mathrm{mol}^{-1}\right)$, though such products were not experimentally observed. ${ }^{31,32}$ Besides, as DFT-computed, $\mathrm{HSiEt}_{3}$ cleavage mediated by 3 is even more accessible in the presence of an alkene (propene as model) to afford $\left[\left(\mathrm{HexCB}_{11} \mathrm{Cl}_{11}\right) \mathrm{Zn}-\mathrm{H}\right]$ and cation $\left[(\operatorname{propyl}) \mathrm{SiEt}_{3}\right]^{+}\left(\Delta \mathrm{G}=9.2 \mathrm{~kJ} \cdot \mathrm{mol}^{-1}\right)$. In view of the latter and for comparison with $\mathbf{3}$, hydrosilylation of methylcyclohexene catalyzed by $\left[\mathrm{Ph}_{3} \mathrm{C}\right]\left[\mathrm{HexCB}_{11} \mathrm{Cl}_{11}\right]\left(1 \%\right.$ mol vs. $\left.\mathrm{HSiEt}_{3}, \mathrm{RT}, \mathrm{C}_{6} \mathrm{D}_{5} \mathrm{Br}\right),{ }^{33}$ was studied: it was found to proceed with a similar rate (quantitative within $15 \mathrm{~min}$ ) and selectivity with the formation of the cis-product 5, as typically observed in silylium-catalyzed alkene hydrosilylation. ${ }^{30,34,35}$ Altogether, though no clear-cut mechanism may be proposed at this stage, DFT and experimental data strongly suggest the involvement of a transient silylium cation, generated from the reaction of $\mathbf{3}$ with $\mathrm{HSiEt}_{3}$, to account for the observed catalytic activity and selectivity in alkene hydrosilylation. 


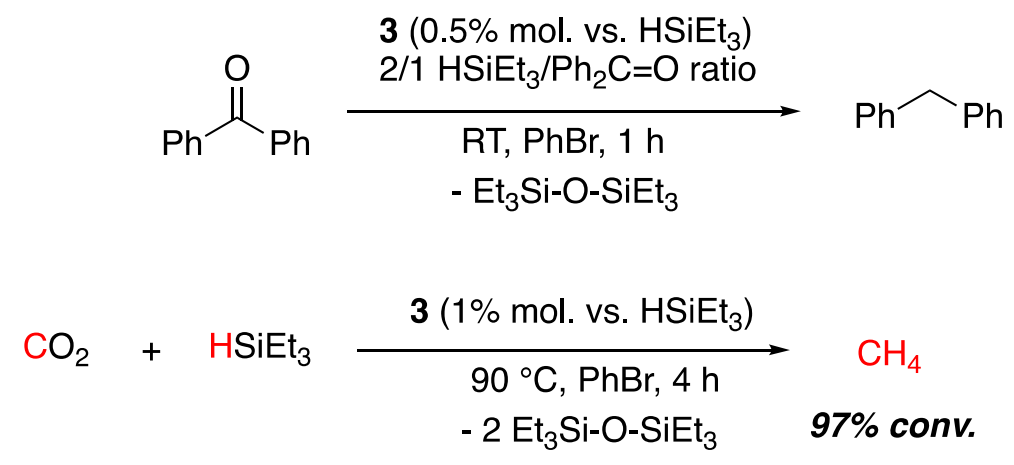

Scheme 4. Hydrosilylation of $\mathrm{C}=\mathrm{O}$ substrates catalyzed by species $\mathbf{3}$.

Species 3 was also tested in hydrosilylation/deoxygenation catalysis of $\mathrm{C}=\mathrm{O}$ substrates (Scheme 4). In the presence of $3(1 \mathrm{~mol} \%)$, a $1 / 1$ mixture of benzophenone/HSiEt $3\left(\mathrm{C}_{6} \mathrm{D}_{5} \mathrm{Br}\right.$, RT, $5 \mathrm{~h}$, not optimized) led to the formation of doubly reduced product $\mathrm{Ph}_{2} \mathrm{CH}_{2}$ (50\% conv) along with side-product $\mathrm{Et}_{3} \mathrm{SiOSiEt}_{3}$ and $50 \%$ of unreacted $\mathrm{Ph}_{2} \mathrm{C}=\mathrm{O}$, based on ${ }^{1} \mathrm{H}$ NMR data. Starting from a $1 / 100 / 2003 / \mathrm{Ph}_{2} \mathrm{C}=\mathrm{O} / \mathrm{HSiEt}_{3}$ mixture led to an $80 \%$ conversion of $\mathrm{Ph}_{2} \mathrm{C}=\mathrm{O}$ to reduction products $\mathrm{PhCH}-\mathrm{OSiEt} 3 / \mathrm{Ph}_{2} \mathrm{CH}_{2}$ in a $1 / 15$ ratio within 15 min at $\mathrm{RT}$. A complete formation of $\mathrm{PhCH}_{2} \mathrm{Ph}$ (along with equimolar amount of $\mathrm{Et}_{3} \mathrm{SiOSiEt}_{3}$ ) occurred within $1 \mathrm{~h}$ at room temperature in $\mathrm{C}_{6} \mathrm{D}_{5} \mathrm{Br}$. Interestingly, $\mathrm{CO}_{2}$, a more challenging $\mathrm{C}=\mathrm{O}$ substrate, may also be reduced by $\mathrm{HSiEt}_{3}$ in the presence of $\mathbf{3}$ as catalyst. An initial run at room temperature (10 mol\% of 3, 1.5 atm $\mathrm{CO}_{2}, \mathrm{C}_{6} \mathrm{D}_{5} \mathrm{Br}$ ) showed slow $\mathrm{CO}_{2}$ hydrosilylation (15\% silane conversion after $60 \mathrm{~h}$ ) with the observation of reduction products $\mathrm{Et}_{3} \mathrm{SiOCH}_{2} \mathrm{OSiEt}_{3}, \mathrm{MeOSiEt}_{3}$ and eventually $\mathrm{CH}_{4}$ as the reduction reaction proceeds. ${ }^{36}$ However, satisfyingly, species 3 (1 mol\% vs. $\mathrm{HSiEt}_{3}$ ) efficiently and selectively catalyzed $\mathrm{CO}_{2}$ hydrosilylation upon heating (1.5 atm $\mathrm{CO}_{2}, \mathrm{C}_{6} \mathrm{D}_{5} \mathrm{Br}, 90{ }^{\circ} \mathrm{C}$ ) with a nearly quantitative conversion of $\mathrm{HSiEt}_{3}(97 \%)$ to methane and $\mathrm{SiEt}_{4} /$ siloxanes by-products within $4 \mathrm{~h}$, as deduced from NMR and GC-MS data (SI). Remarkably, as a Lewis acid catalyst in $\mathrm{CO}_{2}$ hydrosilylation, species $\mathbf{3}$ is considerably more active than any other $\mathrm{Zn}(\mathrm{II})$ cations such as $\left[\mathrm{EtZn}\left(\mathrm{C}_{6} \mathrm{H}_{6}\right)\right]\left[\mathrm{CHB}_{11} \mathrm{Cl}_{11}\right]$, two-coordinate $[(\mathrm{NHC}) \mathrm{Zn}-\mathrm{R}]^{+}$systems and even group 13 metal cations of the type $\left[\mathrm{MR}_{2}\right]^{+}(\mathrm{M}=\mathrm{Al}, \mathrm{Ga})$ 
thus far reported. ${ }^{20 \mathrm{a}, 20 \mathrm{c}, 37}$ No adduct formation was observed between $\mathbf{3}$ and $\mathrm{CO}_{2}$ at various temperatures (1.5 atm $\mathrm{CO}_{2}, \mathrm{C}_{6} \mathrm{D}_{5} \mathrm{Br}$ ) according to ${ }^{13} \mathrm{C}$ data recorded from $-20{ }^{\circ} \mathrm{C}$ to $90{ }^{\circ} \mathrm{C}$. Under the studies' conditions and given the reactivity of 3 with $\mathrm{HSiEt}_{3}$ (vide supra), $\mathrm{CO}_{2}$ hydrosilylation catalysis by $\mathbf{3}$ is likely to proceed through the initial involvement of cation

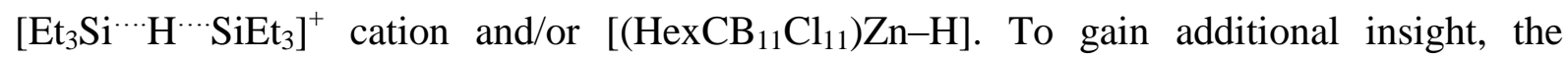
relative performances of $\mathbf{3}$ vs. $\left[\mathrm{Et}_{3} \mathrm{Si}^{\cdots \cdots} \mathrm{H}^{\cdots \cdot} \mathrm{SiEt}_{3}\right]^{+}$were contrasted. Thus, $\mathrm{CO}_{2}$ hydrosilylation initiated by $\left[\mathrm{Ph}_{3} \mathrm{C}\right]\left[\mathrm{HexCB}_{11} \mathrm{Cl}_{11}\right]\left(1 \%\right.$ mol vs. $\left.\mathrm{HSiEt}_{3}, 70{ }^{\circ} \mathrm{C}, 2.5 \mathrm{~h}, \mathrm{C}_{6} \mathrm{D}_{5} \mathrm{Br}\right)$ proceeded twice as fast as that mediated by $\mathbf{3}(1 \% \mathrm{~mol})$ under identical conditions ( $61 \%$ vs. $30 \%$ conversion of $\mathrm{HSiEt}_{3}$, respectively), both catalysis yielding methane as the only reduction product. ${ }^{38}$ The latter could be consistent with cation $\left[\mathrm{Et}_{3} \mathrm{Si}^{\cdots} \mathrm{H}^{\cdots} \mathrm{SiEt}_{3}\right]^{+}$being the catalytically active component upon associating $\mathbf{3}$ and $\mathrm{HSiEt}_{3}$, with a lower activity due to a smaller concentration in silylium as the catalysis proceeds. Though a few ligand-supported $\mathrm{Zn}-\mathrm{H}^{+}$ cations are known to effectively reduce $\mathrm{CO}_{2}$ under similar reaction conditions to ours, ${ }^{39}$ the possible inactivity of a nearly "naked" $\mathrm{Zn}-\mathrm{H}$ moiety such as $\left[\left(\mathrm{HexCB}_{11} \mathrm{Cl}_{11}\right) \mathrm{Zn}-\mathrm{H}\right]$ could be due to its decomposition under such conditions.

Finally, in preliminary studies, highly Lewis acidic species $\mathbf{3}$ was also tested in transfer hydrogenation of alkenes using 1,4-cyclohexadiene (CHD) as hydrogen source, a very convenient and safe $\mathrm{H}_{2}$ surrogate. Such hydrogenations may be catalyzed by gallium or boron Lewis acidic complexes, though heating and long reaction times are frequently required. ${ }^{40} \mathrm{~A} \mathrm{Zn}(\mathrm{II})$ cation was also recently reported to catalyze hydrogenation transfer of 1,1-diphenylethylene at $80{ }^{\circ} \mathrm{C}$ with $24 \mathrm{~h}$ using $10 \mathrm{~mol} \%$ of catalyst. ${ }^{41}$ Satisfyingly, species 3 ( 2 mol\% vs. substrates) performed much better and efficiently catalyzed 1,1-diphenylethylene hydrogenation to $\mathrm{Ph}_{2} \mathrm{CH}-\mathrm{CH}_{3}$ at room temperature in the presence of $\mathrm{CHD}$ within $3 \mathrm{~h}$ (Scheme 5), further illustrating the strong Lewis acidity of the $\mathrm{Zn}^{2+}$ center of $\mathbf{3}$. 


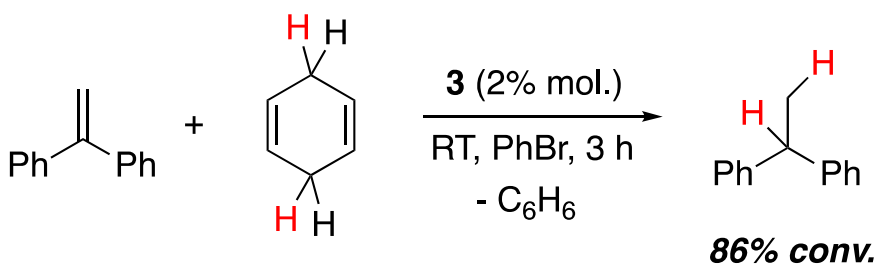

Scheme 5. Transfer hydrogenation of 1,1-diphenylethylene catalyzed by species 3 .

In conclusion, we synthesized and characterized the first example of a compound incorporating a formal $\mathrm{Zn}^{2+}$ cation only stabilized by weakly coordinating anions, that is stable at room temperature and soluble in low polarity organic solvents. Based on its reactivity with various substrates, it stands as a strong (perhaps the strongest) $\mathrm{Zn}$-based Lewis acid in solution thanks to ready anion dissociation even in a low-basicity solvent such as $\mathrm{PhBr}$. It constitutes an important step forward towards a "naked" $\mathrm{Zn}$ (II) dication in the condensed phase, i.e. a compound in which cation $\cdots$ anion interactions are minimized as far as possible. Further reactivity studies of such $\mathrm{Zn}$ (II) dications for the activation of various small molecules as well as access to other "naked" metal cations are currently underway in our labs.

Acknowledgments. The CNRS and the University of Strasbourg are gratefully thanked for financial support. Part of this work was also supported by the Agence Nationale de la Recherche (ANR): ANR project Tu-Zin-Cat (ANR-19-CE07-0020-01). N. A. thanks the icFRC (Chemistry Research Foundation of the University of Strasbourg) for a $\mathrm{PhD}$ fellowship. 


\section{References}

[1] Acid Catalysis in Modern Organic Synthesis, Ed.: H. Yamamoto, K. Ishihara, WileyVCH, 2009.

[2] Selected reviews: (a) M. Bochmann, Acc. Chem. Res. 2010, 43, 1267-1278; (b) M. Bochmann, Coord. Chem. Rev. 2009, 253, 2000-2014. (c) T. A. Engesser, M. R. Lichtenthaler, M. Schleep, I. Krossing, Chem. Soc. Rev. 2016, 45, 789-899. (d) D. Franz, S. Inoue, Chem. Eur. J. 2019, 25, 2898-2926. (e) J. C. L. Walker, H. F. T. Klare, M. Oestreich, Nature Rev. Chem. 2020, 4, 54-62.

[3] (a) I. M. Riddlestone, A. Kraft, J. Schaefer, I. Krossing, Angew. Chem. Int. Ed. 2018, 57, 13982-14024 (b) C. A. Reed, Acc. Chem. Res. 1998, 31, 133-139.

[4] K. Fujiki, S.-Y. Ikeda, H. Kobayashi, A. Mori, A. Nagira, J. Nie, T. Sonoda, Y. Yagupolskii, Chem. Lett. 2000, 1, 62-63.

[5] Y. Kitazawa, R. Takita, K. Yoshida, A. Muranaka, S. Matsubara, M. Uchiyama, J. Org. Chem. 2017, 82, 1931-1935.

[6] M. R. Lichtenthaler, S. Maurer, R. J. Mangan, F. Stahl, F. Mönkemeyer, J. Hamann, I. Krossing, Chem. - Eur. J. 2015, 21, 157-165.

[7] (a) K. M. Osman, D. R. Powell, R. J. Wehmschulte, Inorg. Chem. 2015, 54, 9195-9200.

(b) R. J. Wehmschulte, R. Peverati, D. R. Powell, Inorg. Chem. 2019, 58, 12441-12445.

[8] Z. Xie, C.-W. Tsang, E. T.-P. Sze, Q. Yang, D. T. W. Chan, T. C. W. Mak, Inorg. Chem. 1998, 37, 6444-6451.

[9] C. A. Reed, Acc. Chem. Res. 1998, 31, 133-139.

[10] I. Krossing, Chem. - Eur. J. 2001, 7, 490-502.

[11] A. Bihlmeier, M. Gonsior, I. Raabe, N. Trapp, I. Krossing, Chem. - Eur. J. 2004, 10, 5041-5051.

[12] (a) S. Pawlenko, Z. anorg. allg. Chem. 1962, 315, 136-146. (b) B. Frlec, D. Gantar, J. H. Holloway, J. Fluorine Chem. 1982, 19, 485-500.

[13] V. Nguyen-Duc. New Salt-Like Dodecahydro-Closo- Dodecaborates and Efforts for the Partial Hydroxylation of $\left[\mathrm{B}_{12} \mathrm{H}_{12}\right]^{2-}$ Anions. Ph.D. Thesis, Universität Stuttgart, 2009.

[14] Y. Sadikin, E. Didelot, Z. Łodziana, R. Černý, Dalton Trans. 2018, 47, 5843-5849.

[15] T. O. Petersen, E. Tausch, J. Schaefer, H. Scherer, P. W. Roesky, I. Krossing, Chem. Eur. J. 2015, 21, 13696-13702.

[16] C. Damude, P. A. Dean, J. Organomet.Chem. 1979, 181, 1-15. 
[17] P. Dabringhaus, M. Schorpp, H. Scherer, I. Krossing, Angew. Chem. Int. Ed. 2020, DOI: 10.1002/anie.202010019.

[18] (a) D. A. Walker, T. J. Woodman, D. L. Hughes, M. Bochmann, Organometallics 2001, 20, 3772-3776. (b) S. Garratt, A. Guerrero, D. L. Hughes, M. Bochmann, Angew. Chem. Int. Ed. 2004, 43, 2166-2169. (c) G. Schnee, C. Fliedel, T. Avilés, S. Dagorne, Eur. J. Inorg. Chem. 2013, 3699-3709.

[19] S. Dagorne, Synthesis 2018, 50, 3662-3670.

[20] (a) R. J. Wehmschulte, L. Wojtas, Inorg. Chem. 2011, 50, 11300-11302. (b) M. A. Chilleck, L. Hartenstein, T. Braun, P. W. Roesky, B. Braun, Chem. - Eur. J. 2015, 21, 25942602. (c) D. Specklin, F. Hild, C. Fliedel, C. Gourlaouen, L. F. Veiros, S. Dagorne, Chem. Eur. J. 2017, 23, 15908-15912.

[21] E. S. Stoyanov, K.-C. Kim, C. A. Reed, J. Am. Chem. Soc. 2006, 128, 8500-8508.

[22] The collected colorless solid was soluble enough for ${ }^{1} \mathrm{H}$ and ${ }^{11} \mathrm{~B}$ NMR data, which are consistent with the formation of $\mathrm{Zn}\left[\mathrm{CHB}_{11} \mathrm{Cl}_{11}\right]_{2}$.

[23] The syntheses of the $\mathrm{Na}^{+}$and $\left[\mathrm{Me}_{3} \mathrm{NH}\right]^{+}$salts of $\left[\mathrm{HexCB}_{11} \mathrm{Cl}_{11}\right]^{-}$have been reported in $\mathrm{R}$. Ramirez-Contreras, O. V. Ozerov, Dalton Trans. 2012, 41, 7842-7844.

[24] A PhBr adduct of a $\mathrm{Zn}$ (II) organocation was recently characterized in the solid state, see ref. 20c.

[25] DFT calculations also agree with dissociation of $\mathrm{Zn}\left[\mathrm{HexCB}_{11} \mathrm{Cl}_{11}\right]_{2}$ to $\left[\mathrm{Zn}\left(\mathrm{HexCB}_{11} \mathrm{Cl}_{11}\right)\right]^{+}$and free $\left[\mathrm{HexCB}_{11} \mathrm{Cl}_{11}\right]^{-}$anion being energetically accessible under the studied conditions $\left(\Delta \mathrm{G}=34.7 \mathrm{~kJ} \cdot \mathrm{mol}^{-1}\right)$.

[26] Experimental estimation of the Lewis acidity of species 3 through the Guttmann-Beckett method was inconclusive.

[27] For a recent review on strong Lewis acids and estimation of their Lewis acidity through FIA, see: L. Greb, Chem. -Eur. J. 2018, 24, 17881-17896.

[28] For an alkene adduct of a strong Lewis acid such as $\mathrm{Al}\left(\mathrm{C}_{6} \mathrm{~F}_{5}\right)_{3}$, see: G. Ménard, D. W. Stephan, Angew. Chem. Int. Ed. 2012, 51, 8272-8275.

[29] M. C. Lipke, A. L. Liberman-Martin, T. D. Tilley, Angew. Chem. Int. Ed. 2017, 56, 2260-2294. 
[30] Recent review on hydrosilylation catalysis by boranes: M. Oestreich, J. Hermeke, J.

Mohr, Chem. Soc. Rev. 2015, 44, 2202-2220.

[31] The formation of $\mathrm{Zn}^{\cdots} \mathrm{H}-\mathrm{SiEt}_{3}$ adduct $\left[\left(\mathrm{HexCB}_{11} \mathrm{Cl}_{11}\right) \mathrm{Zn}\left(\mathrm{HSiEt}_{3}\right)\right]^{+}$and free $\left[\mathrm{HexCB}_{11} \mathrm{Cl}_{11}\right]^{-}$is possible at low energy cost $\left(\Delta \mathrm{G}=25.9 \mathrm{~kJ} \cdot \mathrm{mol}^{-1}\right)$. From the latter and in the presence of 1 equiv of $\mathrm{HSiEt}_{3}, \mathrm{HSiEt}_{3}$ heterolytic cleavage to the $\mathrm{Zn}-\mathrm{H}$ species $\left[\left(\mathrm{HexCB}_{11} \mathrm{Cl}_{11}\right) \mathrm{Zn}-\mathrm{H}\right]$ and the silylium cation $\left[\mathrm{Et}_{3} \mathrm{Si}^{\cdots \cdot} \mathrm{H}^{\cdots} \mathrm{SiEt}_{3}\right]^{+}$requires no energy $(\Delta \mathrm{G}=$ $\left.0.0 \mathrm{~kJ} \cdot \mathrm{mol}^{-1}\right)$.

[32] ${ }^{29} \mathrm{Si}$ and ${ }^{1} \mathrm{H}$ NMR spectra of a $1 / 2 \mathbf{3} \mathrm{HSiEt}_{3}$ mixture (recorded at $\mathrm{RT}$ and at $90{ }^{\circ} \mathrm{C}$, $\mathrm{C}_{6} \mathrm{D}_{5} \mathrm{Br}$ ) only contain resonances for the starting reagents, with no observation of $\mathrm{Zn}-\mathrm{H}$ and silylium moieties. IR data of a 1/2 3/ $\mathrm{HSiEt}_{3}$ mixture (RT, $\mathrm{PhBr}$ ) were inconclusive.

[33] The reaction of trityl carborate species with excess $\mathrm{R}_{3} \mathrm{SiH}(\mathrm{R}=\mathrm{Me}, \mathrm{Et})$ is well-known to afford the corresponding $\left[\mathrm{R}_{3} \mathrm{Si}-\mathrm{H}-\mathrm{SiR}_{3}\right]^{+}$cation and carborate anion as dissociated ions, see: S. P. Hoffmann, T. Kato, F. S. Tham, C. A. Reed, Chem. Commun. 2006, 767-769.

[34] (a) J. M. Blackwell, K. L. Foster, V. H. Beck, W. E. Piers, J. Org. Chem. 1999, 64, 48874892. (b) D. J. Parks, J. M. Blackwell, W. E. Piers, J. Org. Chem. 2000, 65, 3090-3098. (c) M. Rubin, T. Schwier, V. Gevorgyan, J. Org. Chem. 2002, 67, 1936-1940.

[35] (a) M. Nava, C. A. Reed, Organometallics 2011, 30, 4798-4800. (b) A. Y. Houghton, J. Hurmalainen, A. Mansikkamäki, W. E. Piers, H. M. Tuononen, Nat. Chem. 2014, 6, 983-988; (c) J. Chen, E. Y. X Chen, Angew. Chem. Int. Ed. 2015, 54, 6842-6846.

[36] For literature data on $\mathrm{Et}_{3} \mathrm{SiOCH}_{2} \mathrm{OSiEt}_{3}, \mathrm{MeOSiEt}_{3}$ and $\mathrm{CH}_{4}$ in $\mathrm{PhBr}$, see: J. Chen, $\mathrm{L}$. Falivene, L. Caporaso, L. Cavallo, E. Y.-X. Chen, J. Am. Chem. Soc. 2016, 138, 5321-5333.

[37] (a) M. Khandelwal, R. J. Wehmschulte, Angew. Chem. Int. Ed. 2012, 51, 7323-7326. (b) M. Saleh, D. R. Powell, R. J. Wehmschulte, Organometallics 2017, 36, 4810-4815.

[38] For representative examples of Lewis acid-type mechanisms for $\mathrm{CO}_{2}$ hydrosilylation with the initial functionalization of $\mathrm{CO}_{2}$ to formate $\mathrm{HCO}_{2} \mathrm{SiEt}_{3}$ and the subsequent formation of $\mathrm{Et}_{3} \mathrm{SiOCH}_{2} \mathrm{OSiEt}_{3}, \mathrm{MeOSiEt}_{3}$ and eventually $\mathrm{CH}_{4}$, see refs. 36, 37 and 20c.

[39] (a) A. Rit, A. Zannardi, T. P. Spaniol, L. Maron, J. Okuda, Angew. Chem. Int. Ed. 2014, 53, 13273-13277. (b) F. Ritter, T. P. Spaniol, I. Douair, L. Maron, J. Okuda, Angew. Chem. Int. Ed. 10.1002/anie.202011480

[40] (a) B. Michelet, C. Bour, V. Gandon, Chem. Eur. J. 2014, 20, 14488-14492, (b) I. Chatterjee, Z.-W. Qu, S. Grimme, M. Oestreich, Angew. Chem. Int. Ed. 2015, 54, 1215812162. 
[41] J. Tian, Y. Chen, M. Vayer, A. Djurovic, R. Guillot, R. Guermazi, S. Dagorne, C. Bour, V. Gandon, Chem. - Eur. J. 2020, 26, 12831-12838. 